\title{
THE INFLUENCE OF ECO-MATERIALS ONFURNITURE AND INTERIOR PRODUCTION IN MACEDONIA
}

\author{
Petar Namicev $^{1}$, Viktorija Tasevska ${ }^{2}$ \\ ${ }^{1,2}$ University Goce Delcev Shtip, Republic of Macedonia \\ petar.namicev@ugd.edu.mk, viktorijatasevska@hotmail.com
}

\section{Professional Paper \\ doi:10.5937/jouproman6-19121}

\begin{abstract}
The modern style of living very often dictates us to spend great part of our time in a working atmosphere i.e. in business space with business services, in restaurants, as well as in hotels. That is why it is very important these kinds of environment to be planned in a way that would remind us on a cozy domestic atmosphere.
\end{abstract}

In the interiors, sustainable materials still have the epithet of timeless materials which never go out of fashion. However, the special moment in choosing the material depends on an individual's lifestyle.

Recently, more emphasis is put on the quality and longevity of natural (eco) materials, because not only they are good for people and living environment, but also the same ones are with an unsurpassed quality. The materials used as their replacement cost less, but their quality is not nearly with the same quality and longevity.

The term eco-material represents a term which widely includes natural resources derived directly from nature, and the same ones can be used for various projects in interior design. With the use of natural materials in the home, there is a warm feeling which is also felt in the nature itself.

In Macedonia the use of eco -materials is different, depending on the type of production of the furniture manufacturing companies. On the basis on the researches that I made of some Macedonian companies of this type, you will learn what materials, and in what percent and what purpose they are used for.

Key words: Ecological, green, design, material, furniture design, interior design.

\section{Introduction:}

The green or eco- friendly interior design includes design- solutions of interiors which include the use of ecomaterials used to design the look and the atmosphere of the home. With the use of eco-friendly interior design, not only that it positively influences health of people living in this type of home, but it also captures harmony of the interior, which gives itself a feeling of tranquility and fulfillment, and yet reduces the living costs in the home.

(Carla J. Nilson, David A. Taylor, 2012).

"The interior is natural protection of the soul." - Coco Chanel

The concept eco-design in the section of construction is defined as: "creation and responsible management of healthy built living environment, based on effective use of resources and ecological principles."

Ecological and green design represents any form of design which minimizes ecological destructive influences with emulation and integrity with natural eco systems, well known as eco-design. 
As such, the eco-design strives to provide a framework of ecological adequate system of design and management with incorporation of anthropogenic ecological values, in spatial time scales. (Fan Shu-Yang, F. Freedman, B. and Cote,R.2004).

The principles of eco-design can be applied within framework of continuum of spatial dimensions, such as individual homes, settlements, industrial zones, as well as making products. Therefore it can be concluded that eco-design can be applied for improvement of the already existing environments, also for planning new ones. It can also be used widely in the development and production of certain products.

With continuous increase of human population and industrial production, also grows the concern for the living environment, and the main reason for this is extraction and use of materials, use of products and their final recycling or destruction. Within the framework of this context, eco-design is well known as a strategy which is applied for reduction of influences in connection with production and consumption of products.

According to what has been said so far, interior architecture as a discipline controls design of interior space, and also it has a potential to control and give direction to ecological and green parameters of interior design. (W. Wimer, 2004).

\section{Application of eco-material in Macedonia}

Materials are part of our everyday life. They are met in every single segment by which we are surrounded, and depending on their type they are characterized with the a variety of features. The choice of material for a given product is vital. It spends natural resources as much as needed energy for production. It is based on technical needs such as: price, hardness, temperature stability, density, as well as resistance of the material itself. (Mike Ashby, Kara Johnson Elesevier, 2002).

Natural or eco-materials represent materials derived directly from nature can be used for different types of projects for home design, where they give the home the warm atmosphere felt in nature. Natural materials used in interior design are: wood, bamboo, wooden girders, stones, leather, metals etc.

On the basis on researches made for eco materials and their use in the world, I have made a survey in some Macedonian furniture manufacturing companies, as well as their use of eco materials in their production:

1. SIMPL - MEBEL (established in 1998, in Radovish with activity production of upholstered furniture).

2. GUN INTERIER(established in 1990 in Gostivar, with activity production of dining Room tables and chairs and club tables).

3. JUMIS (established 2008 in Kochani, with activity - production of upholstered furniture and flat surfaces).

4. DRVO PRODUKT (established in 2002 in Pehchevo, with activity production of dining tables and chairs and club tables).

\section{ZLATEV INJINERING} (established in 2016 in Shtip, with activity- production of flat furniture).

6. PIRAMIDA (established in 1993 in Strumica, with activity production of flat furniture.

On the graphic display, a percentage presence is represented of ecomaterials: 


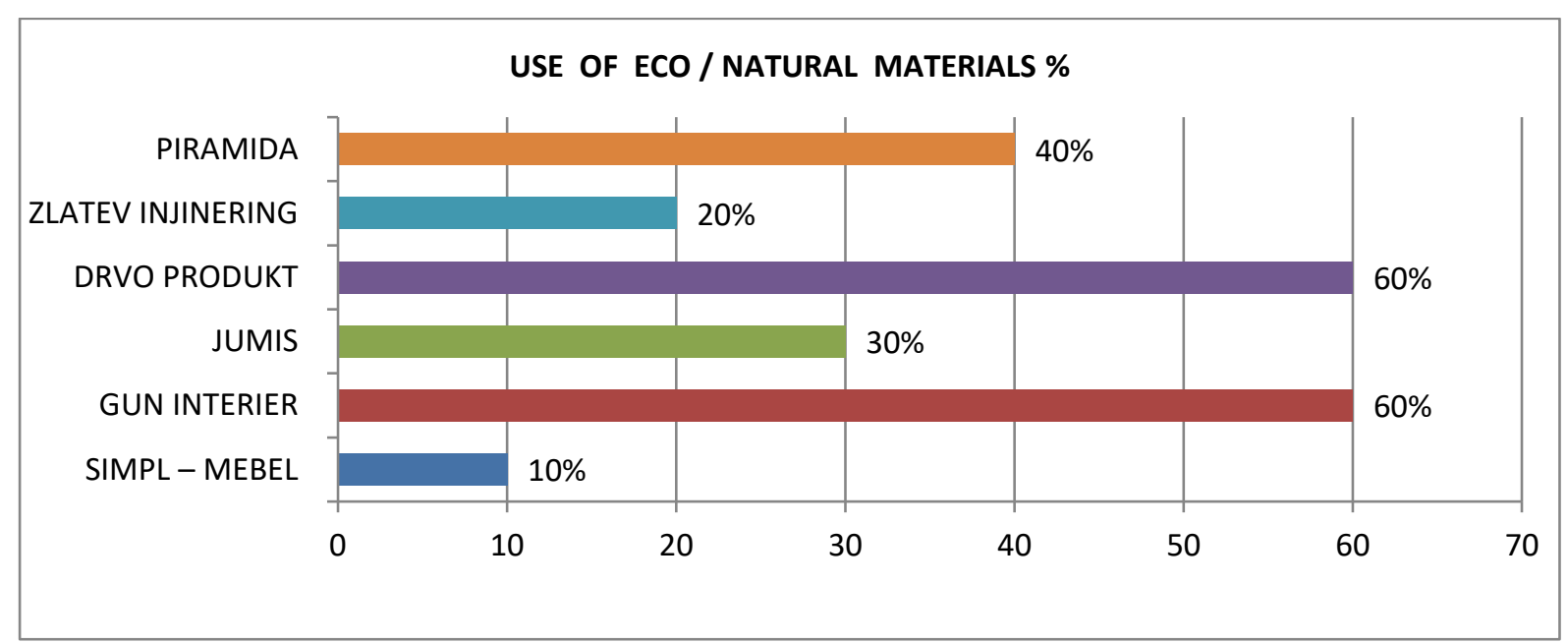

Chart 1 : Use of eco/ natural materials in Macedonia

From the graphic display it can be noticed that according to the type of the furniture produced by the Macedonian companies, eco materials are used for different purposes. So the percentage use of the eco materials depends on the purpose of the companies. The companies which produce dining tables and chairs, use eco- materials for making a construction of their products, while, the rest of them use these materials for production of details, or for fastening and twisting of the construction of the product.
However, during their production it can be noticed a use of artificial conventional materials whose use is much more present than the one of the ecomaterials.

On the graphic display, a percentage presence is represented of ecomaterials and also of artificial conventional materials, used by the surveyed companies.

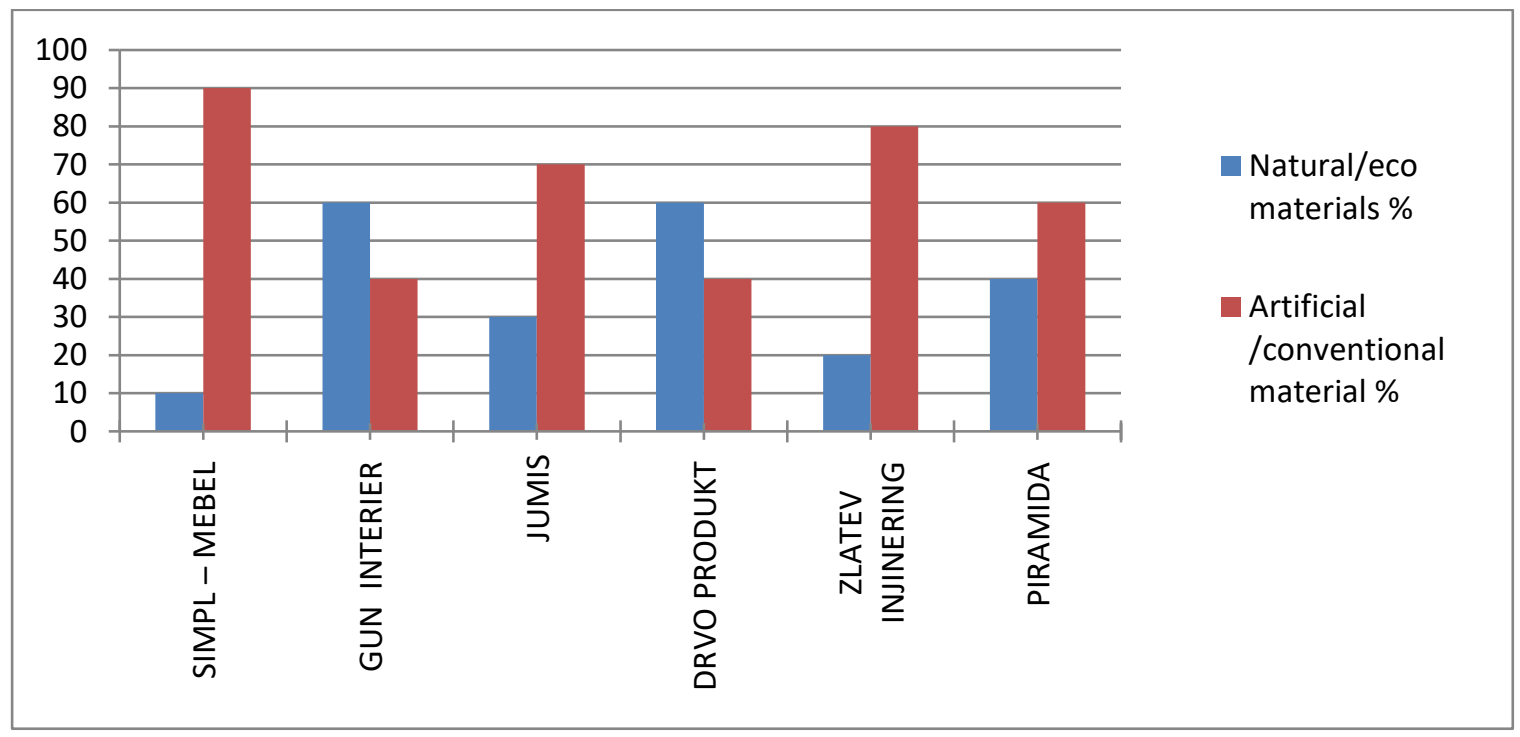

Chart 2: Use of eco materials versus conventional materials in Macedonia 
For each company a different percent of the use of eco material is noticed, but still, it is on a lower level in relation to the application of the use of conventional material.

Often in selecting materials, the crucial role have some decisive factors, among which are quality and economic factor.
In continuation, on the graphic display, the quality and economic factor are represented with their influence of the selection of materials, which are supposed to be used by the surveyed companies, for production of their products:

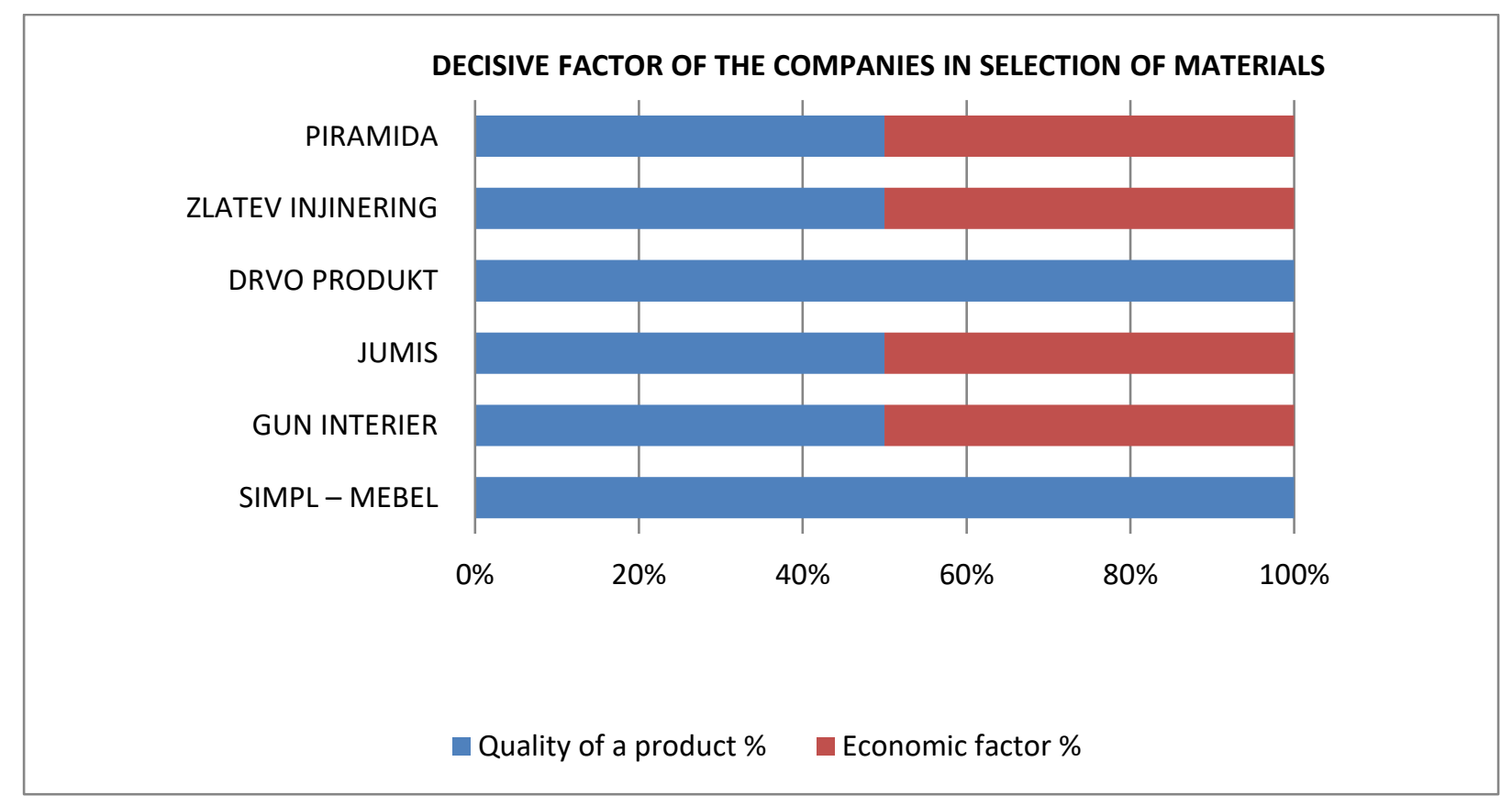

Chart 3: An influential factor in the selection of materials among the surveyed firms in Macedonia

From the graphic display it can be seen that, in general, the companies in Macedonia strive to use materials which will give a good quality of a product, but at the same time they will also satisfy the economic factor, i.e. they will not be too expensive (GUN INTERIER, JUMIS, ZLATEV INZHINERING and PIRAMIDA); there are also companies which put quality on the first place, not paying attention how the same one would influence the final price of the product (SIMPL - M and DRVO PRODUKT).

Materials used by the companies supplied from various markets, and their percentage relation are presented in the following graphic display: 


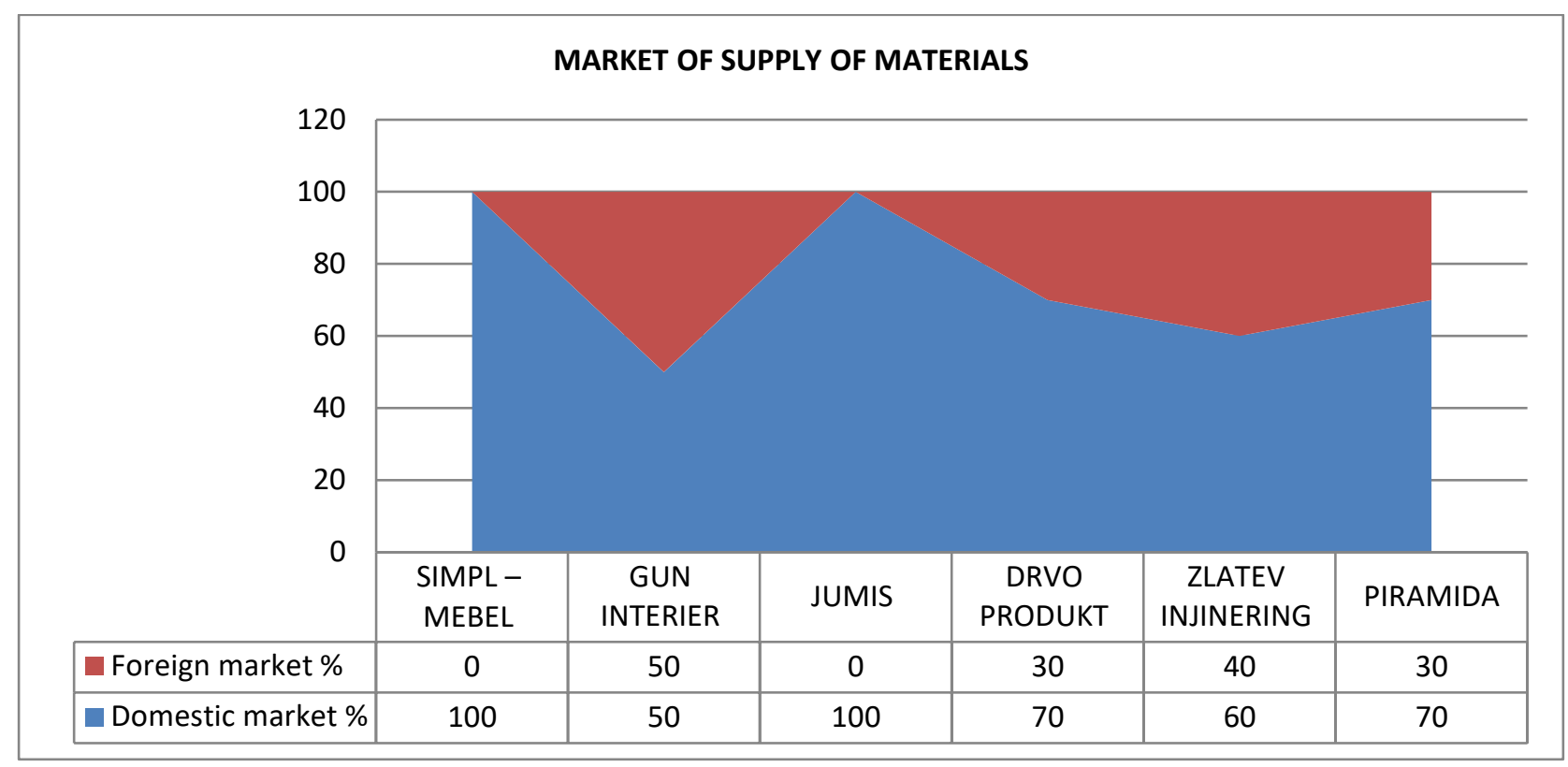

Chart 4: Market of supply of materials to the surveyed firms in Macedonia

From the above given graphic display, it can be concluded again that material used in Macedonian production of furniture are mostly supplied not only from domestic but also from foreign market, but each they are supplied in a different way by each of the companies.

\section{CONCLUSION}

On the basis on the made researches based on natural/eco materials, their characteristics and divisions, as well as the way they are used, a survey of a few companies in Macedonia for furniture production was made, from the surveyed results it can be concluded that in $\mathrm{R}$. Macedonia, the companies for furniture production use eco-materials for different use and in percentage. In general, these eco-material are used by the companies which make dining tables and chairs, for production of design constructions. The other companies which make corporeal furniture and sitting furniture, mostly use artificially made material, while eco materials are used by them to make details or for tightening of the product construction. 
(JPMNT) Journal of Process Management - New Technologies, International

Vol. 6, No 4, 2018.

\begin{tabular}{|c|c|c|c|c|c|c|}
\hline $\begin{array}{l}\text { SURVEYED } \\
\text { FIRM }\end{array}$ & $\begin{array}{l}\text { SIMPL - } \\
\text { MEBEL } \\
\text { Radovish }\end{array}$ & $\begin{array}{c}\text { GUN } \\
\text { INTERIER } \\
\text { Gostivar }\end{array}$ & $\begin{array}{l}\text { JUMIS } \\
\text { Kochani }\end{array}$ & $\begin{array}{c}\text { DRVO } \\
\text { PRODUK } \\
\text { T } \\
\text { Pehchevo }\end{array}$ & $\begin{array}{c}\text { ZLATEV } \\
\text { INJINERING } \\
\text { Shtip }\end{array}$ & $\begin{array}{c}\text { PIRAMIDA } \\
\text { Strumica }\end{array}$ \\
\hline PRODUCTION & Upholstery & $\begin{array}{l}\text {-Dining } \\
\text { chairs } \\
\text {-Dining } \\
\text { table } \\
\text { - Coffee } \\
\text { table }\end{array}$ & $\begin{array}{l}\text {-Upholstery } \\
\text {-Flat } \\
\text { surfaces }\end{array}$ & $\begin{array}{l}\text {-Dining } \\
\text { chairs } \\
\text {-Dining } \\
\text { table } \\
\text { - Coffee } \\
\text { table }\end{array}$ & Flat furniture & Flat furniture \\
\hline $\begin{array}{c}\text { USED } \\
\text { MATERIALS }\end{array}$ & $\begin{array}{l}\text {-Wood } \\
\text {-Metal } \\
\text { - Plywood } \\
\text {-PU soft } \\
\text { foam } \\
\text {-Furniture } \\
\text { fabric }\end{array}$ & $\begin{array}{l}\text {-Massive } \\
\text { wood } \\
\text { - Steamy } \\
\text { beech } \\
\text {-Boards } \\
\text {-Wood glue } \\
\text {-Water } \\
\text { paint } \\
\text {-Acrylic } \\
\text { paint } \\
\text {-PU soft } \\
\text { foam } \\
\text {-Eco- } \\
\text { leather/ } \\
\text { furniture } \\
\text { fabric }\end{array}$ & $\begin{array}{l}\text {-Wood } \\
\text {-Metal } \\
\text { - Plywood } \\
\text {-PU soft } \\
\text { foam } \\
\text {-Furniture } \\
\text { fabric } \\
\text { - Leather } \\
\text { - Glass } \\
\text { - Boards }\end{array}$ & $\begin{array}{l}\text {-Massive } \\
\text { wood } \\
\text { - Steamy } \\
\text { beech } \\
\text {-Boards } \\
\text {-Wood glue } \\
\text {-Water } \\
\text { paint } \\
\text {-Acrylic } \\
\text { paint } \\
\text {-PU soft } \\
\text { foam } \\
\text {-Eco- } \\
\text { leather/ } \\
\text { furniture } \\
\text { fabric }\end{array}$ & $\begin{array}{l}\text {-Wood } \\
\text {-Boards } \\
\text { - Plywood } \\
\text { - Cork }\end{array}$ & $\begin{array}{l}\text {-Wood } \\
\text {-Boards } \\
\text { - Plywood } \\
\text {-Metal }\end{array}$ \\
\hline $\begin{array}{c}\text { TYPE OF } \\
\text { MATERIALS }\end{array}$ & $\begin{array}{c}10 \% \\
\text { Natural } \\
\\
90 \% \\
\text { Artificial }\end{array}$ & $\begin{array}{c}60 \% \\
\text { Natural } \\
\\
40 \% \\
\text { Artificial }\end{array}$ & $\begin{array}{c}30 \% \\
\text { Natural } \\
\\
70 \% \\
\text { Artificial }\end{array}$ & $\begin{array}{c}60 \% \\
\text { Natural } \\
\\
40 \% \\
\text { Artificial }\end{array}$ & $\begin{array}{c}20 \% \\
\text { Natural } \\
\\
80 \% \\
\text { Artificial }\end{array}$ & $\begin{array}{c}40 \% \\
\text { Natural } \\
\\
60 \% \\
\text { Artificial }\end{array}$ \\
\hline $\begin{array}{c}\text { DECISIVE } \\
\text { FACTOR OF } \\
\text { THE } \\
\text { COMPANIES IN } \\
\text { SELECTION OF } \\
\text { MATERIALS? }\end{array}$ & $\begin{array}{l}100 \% \\
\text { Quality }\end{array}$ & $\begin{array}{c}50 \% \\
\text { Quality } \\
50 \% \\
\text { Economic } \\
\text { factor }\end{array}$ & $\begin{array}{c}50 \% \\
\text { Quality } \\
50 \% \\
\text { Economic } \\
\text { factor }\end{array}$ & $\begin{array}{l}100 \% \\
\text { Quality }\end{array}$ & $\begin{array}{l}50 \% \text { Quality } \\
50 \% \text { Economic } \\
\text { factor }\end{array}$ & $\begin{array}{c}50 \% \\
\text { Quality } \\
50 \% \\
\text { Economic } \\
\text { factor }\end{array}$ \\
\hline
\end{tabular}

Table 1: Survey results from the questioned firms 


\begin{tabular}{|c|c|c|c|c|c|c|}
\hline $\begin{array}{c}\text { MARKET OF } \\
\text { SUPPLY OF } \\
\text { MATERIALS? }\end{array}$ & $\begin{array}{c}100 \% \\
\text { Domestic } \\
\text { market }\end{array}$ & $\begin{array}{c}50 \% \\
\text { Domestic } \\
\text { market } \\
50 \% \\
\text { Foreign } \\
\text { market }\end{array}$ & $\begin{array}{c}100 \% \\
\text { Foreign } \\
\text { market }\end{array}$ & $\begin{array}{c}70 \% \\
\text { Domestic } \\
\text { market } \\
30 \% \\
\text { Foreign } \\
\text { market }\end{array}$ & $\begin{array}{c}60 \% \\
\text { Domestic } \\
\text { market } \\
40 \% \\
\text { Foreign } \\
\text { market }\end{array}$ & $\begin{array}{c}70 \% \\
\text { Domestic } \\
\text { market } \\
30 \% \\
\text { Foreign } \\
\text { market }\end{array}$ \\
\hline $\begin{array}{c}\text { EXPERIENCE } \\
\text { WITH ECO } \\
\text { MATERIALS? }\end{array}$ & 20 years & 28 years & 10 years & 16 years & 2 years & 25 years \\
\hline $\begin{array}{c}\text { THE MOST } \\
\text { USED ECO } \\
\text { MATERIALS? }\end{array}$ & Beech tree & $\begin{array}{l}\text { Massive } \\
\text { wood } \\
\text { steamed } \\
\text { beech }\end{array}$ & Leather & $\begin{array}{l}\text { Massive } \\
\text { wood } \\
\text { steamed } \\
\text { beech }\end{array}$ & $\begin{array}{l}\text {-Beech } \\
\text { tree } \\
\text {-Cork } \\
\text {-Water } \\
\text { paint }\end{array}$ & $\begin{array}{c}\text {-Beech tree } \\
\text {-Eco } \\
\text { boards }\end{array}$ \\
\hline $\begin{array}{c}\text { PART OF } \\
\text { PRODUCTION } \\
\text { BASED ONECO } \\
\text { MATERIALS }\end{array}$ & $\begin{array}{l}\text { Strengthening } \\
\text { the } \\
\text { construction of } \\
\text { products }\end{array}$ & $\begin{array}{l}\text { Construction } \\
\text { of products }\end{array}$ & Upholstery & $\begin{array}{l}\text { Construction } \\
\text { of products }\end{array}$ & Details & $\begin{array}{l}\text { For the } \\
\text { outer part } \\
\text { of the } \\
\text { product } \\
\text { (parts that } \\
\text { are visible) }\end{array}$ \\
\hline $\begin{array}{c}\text { THE MOST } \\
\text { RECEIVED } \\
\text { PRODUCT } \\
\text { BASED ONECO } \\
\text { MATERIALS? }\end{array}$ & / & Chairs & TDF Sets & Chairs & Table & Kitchen \\
\hline
\end{tabular}

Table 2: Survey results from the questioned firms

The reason why Macedonian furniture manufacturers use eco-materials, than the conventional ones, is mostly because of their price. But the question, whether in their further production they would use mostly eco-materials, the most frequent response is positive one, because they are easily maintained, they do not pollute the living environment, and they are long-life materials compared to the artificial ones.

\section{References:}

- Carla J. Nilsson, David A. Taylor Interior Design: introduction: Ars lamina, 2012. - 510 p.: Illustration; $25 \mathrm{~cm}$.

- Emilija Fidancevska, Vineta Srebrenkoska- Materials Engineering: Project Activities in the Tempus Project Tempus 158989-Tempus-1-2009-1-BETempus-

- SAMARDZIOSKA, Todorka, Building Materials / Todorka Samardzioska. Skopje: Faculty of Civil Engineering Skopje, 2015 - 191 pages. : Illustration. ; $20 \mathrm{~cm}$. 
(JPMNT) Journal of Process Management - New Technologies, International

Vol. 6, No 4, 2018.

- H. Stevanovic, A. Jovanovic: Life Cycle Assessment Life Cycle Assessment as an Instrument in Strategic Waste Management Planning, 2010, Monograph in a Stamp.

- W.Wimer, Ecodesign implamantation, Springer 2004 ISBN 1-4020-3070-3

- Spiegel, Ross and Dru Meadows. Green Building Materials - New Jersey: John Wiley and Sons, 2006

- Materials and Design, Mike Ashby and Kara Johnson Elsevier, Butterworth Heinemann, 2002
- Fan Shu-Yang, F., Freedman, B. and Cote, R. "Principles and Practice of Ecological Design" Environmental Review Vol: 12, 2004

- David Pearson, The New Natural House, Ed. Conran, Octobus, 1989

- $\quad$ Forest Products Laboratory. 2010. Wood handbook — Wood as an engineering material. General Technical Report FPLGTR-190. Madison, WI: U.S.Department of Agriculture, Forest Service, Forest Products Laboratory. 508 p. 